\title{
POLITICAL ECONOMY OF DIGITALISATION AND (STATE) NEOLIBERALISM IN CHINA WITH SPECIAL REFERENCE TO 'MADE IN CHINA 2025'
}

\author{
Ramnath Reghunadhan \\ Doctoral Student, Department of Humanities and Social Sciences, Indian \\ Institute of Technology-Madras (IIT-M), Chennai, Tamil Nadu, India \\ E-mail:vrramnath@gmail.com
}

\begin{abstract}
The emergence of cyber-physical systems and digitalisation have but transformed the industrialisation process(es) as well as the global power politics. Currently, China is emerging as a leader in innovation with regard to technologies like the Internet of Things (IoT) related Industrial Revolution (4.0) and is in a transitionary period of integrating it into its manufacturing sector. It is estimated to have the largest growth rate in terms of spending on research and development for the new 'Technological Revolution' and is only behind the leading power USA. Recently, with the institutionalisation of 'Made in China 2025 'strategy, China intends to incorporate the digitalisation process that could help achieve its goal to become a world superpower in manufacturing.
\end{abstract}

Key-words: Digitalisation, China, Political Economy, 'Made in China 2025', State Neoliberalism, Technology

\section{Introduction}

Once, the French Emperor Napolean Bonaparte (1769-1821) during the peak of military conquests to establish an empire believed that China is a sleeping giant with immense potential to control the world. He said, "Let China sleep, for when she wakes she will shake the world" (Fish 2016). China has "woken up' as a power capable of 'shaking' the world, and does not seem to be stopped or ignored by any country in the world. This was possible due to its policies in the post-Mao period that indisputably laid the foundations for reformation of the Chinese economy. Recently, the Chinese government have brought up many policies in entailing the integration of digital technologies into its industrialisation process, with positive as well as negative impact(s) on other nations. Besides, an increased interconnectedness and the emergence of the Fourth Industrial Revolution could be used to increase China's advantage and competitiveness (Schumpeter 1947). This is pertinently important for the 
country, which many consider being an export-led economy and is a major factor for the nation to become a world leader in the coming decades. Interestingly, innovation and industrialisation in China through the cyberspace will elevate it to the status of a hegemon, which according to some scholars would lead to an ancient Chinese imperialist 'tribute system' (朝贡 体制: chaogong tizhi) in the world (Zhang 2013). The particular research questions dealt by the paper are

1) How has (state) neoliberalistic initiatives of the Chinese State transformed the Chinese economy in the post-independence period?

2) How has China rewritten the conventional idea and conception of (Western) neoliberalism?

3) In what ways have the China become a frontline economy undertaking a national-level digitalisation drive?

4) How is the 'Made in China 2025' strategy positioned to disrupt/begin a technological surge and the upcoming challenges to Chinese economy?

The paper analyses the emergence of the Internet of Things (IoT) in China, in relation to the recent 'Made in China 2025' strategy. Interestingly, while unlike the conventional forms of neoliberal development, the paper argues that China has developed its own form of neoliberalism, something with 'Chinese characteristics' integrated into it. The Chinese economy in the postindependence period and the digital foundations are being analysed. The capital-wealth accumulation, particularly in the aftermath of (the '90s) policies and strategies are being entailed within the theoretical framework of (state) neoliberalism in China. The paper also analyses the recent 'Made in China 2025' strategy, its impact and implications, the challenges and initiatives and (counter)measures undertaken to tackle them.

\section{China's Economic Rise: An Overview}

The rise of China was an addendum to its economic might, the 'controlled liberalization' activities, as well as investments in internet infrastructure and related policies. This enabled an increase in foreign investment, domestic demand and increased market access and interconnectivity between various other sectors. Concomitantly, Chinese activities paved way for much more integration of the world economy, a 'globalized global commons' that reached its peak at the beginning of the 21st century. This was more globally accepted when China hosted the 2008 Summer Olympics, which was supplemented by its activities in the digital sphere (Shambaugh 2016). From 1978 until the beginning of 2008, the GDP (Gross Domestic Product) of the country 
increased from 149.5 billion USD to 4.6 trillion USD. The exports provided its highest contribution in 2005-07 when it was nearly one-fourth of the total GDP of China. In '78, China accounted for only 1.74 per cent of the total global GDP it increased to 7.26 per cent in 2007 . Even just before the calamity of Global Financial Crisis (GFC) in 2008, China became the third largest economy in terms of total GDP. It became an economic powerhouse, one which even today enables China to compete and maintain its economic prosperity as well as supremacy, which has entailed it to further the leadership position in different parts of the world. The country had the second highest GDP growth in the preceding seven years before the GFC in 2008 averaging 1,170.41 billion USD annually. This laid the foundation to further strengthening and asserting itself economically as well as politically in the time to come (The World Bank Group 2018b). Currently, it is the largest exporter of goods, produces more than half of steel production, consumes the largest amount of energy and has the largest forex reserves in the world. Interestingly, the country has produced the highest number of millionaires and also the highest number in terms of citizens lifted out of poverty over the past few decades.

\section{1. (State) Neoliberalism in China}

There have been various arguments on the development miracle in China and the influence of neoliberal policies. Interestingly many scholars have argued that neoliberalism does not exist in China, at least based on the traditional notion of the term (as Thatcherism and Reaganism). But many others argue that China has re-invented a neoliberal in its own, at least parts of it based on the requirements and needs calling it State Neoliberalism, State Capitalism and the like (Wu 2010, 619-631; So and Chu 2012). At the beginning of the 21st century Aihwa Ong, a Professor of Anthropology from the University of California based in Berkeley (USA) wrote a book titled Neoliberalism as Exception (2006). In what is considered as a rare seminal work that redefined neoliberalism in the 21st century, she unwaveringly argued how post-Mao China was successful in imbibing 'necessary parts' of the neo-classical model of economic growth that is often considered the dominion of Western and democratic countries. Ong argues that the "state strategies- informed by neoliberal logic-that produce condition for [the] possibility for proliferating... cross-border networks" that involve China, Hong Kong, Macao, Taiwan and Chinese communities in South-East Asia that have led to a kind of regional configuration. She even argues that China "create the political spaces and conditions of variegated sovereignty aligned on the axis of trade, industrialisation and knowledge exchange." According to her, this challenges 
the inherently assumed notion that "economic and political forms of integration develop in different spheres" (Ong 2006, 98).

The idea of Asian and particularly Chinese form of neoliberalism led to the conceptualisation of hybrid forms of neoliberalism, one which focused on understanding the different facets of State systems (Lopes 2017). China became a hub for low-cost manufacturing by prominent companies and brands. The industrial companies in China were to be given preference in gaining foreign investment, with technology transfer made more or less mandatory. Unlike the earlier forms of neoliberal conceptualisation where the Smithian 'Invisible Hand' helped the market to self-correct itself, the Chinese State became the 'Visible Hand' to correct the market and to retain the activities that would lead the economy into development path. Concomitantly, in the 21st century, China overtook every country around the world in terms of GDP per capita and became the second largest in terms of total GDP, just behind the US.

\subsubsection{The Beginning: Phase One}

The rise of modern China began in the mid-latter half of the 20th century, particularly in the late '70s. It was initiated by the then Head of State and Communist Party of China (CPC), Deng Xiaoping through what became known as "reform and opening" (改革开放: gaige kaifang) through a string of incremental liberalisation strategies and policies. Before that China was economically backwards and lacked strong fiscal and monetary foundations to uplift its population from rampant poverty that persisted in the society (Bertram 1996). The problems persisted in the inherent structural deficiencies of China's large state-owned enterprises (SOEs) and industries. The state-owned industries were struggling to provide with viable growth, while funds are being grappled for continuous re-capitalisation. While countries like Germany restructured and reformed the industries, particularly in the aftermath of reunification there was a lot of financial wherewithal available to Germany which is lacking in the case of China. During this period, the Chinese Government has provided a "green light" for the sale of state-owned enterprises in the control of local governments, some of which have been converted into share-holding corporations (Gang 1996).

\subsubsection{The New Century: Phase Two}

On December 11, 2001, in terms of changing perception on China's economic prowess, it joins the WTO, 15 years after it applied for membership under the then General Agreement on Trade and Tariffs (GATT) in 1986 (WTO 2018). Interestingly, unlike the emergence and institutionalisation of the 
Washington Consensus; in the 1980s' China followed an economic model known as "China model," which later came to be known as the Beijing Consensus (originally coined by Joshua Cooper Ramo in 2004) (Shambaugh 2016, 414). During a session of the Council of Sino-Japanese NonGovernmental Persons, Deng Xiaoping described the "China model" of economic development as "building socialism with Chinese characteristics" (China Internet Information Center 1984). Over the years, the Washington Consensus failed in Asia, South America and African continents, the "China model" enabled China to grow at high rates, revitalising the Chinese industrial sector and 'igniting the fire' to the Chinese economy to later outgrow many of the economic superpowers (Rommann 2013). The hallmark tag of Washington consensus; namely policies of deregulation, privatization as well as trade liberalization failed in Asian and South American countries, although it created more trade surpluses for companies and multinational corporations based in US and European countries (Rodrik 2003). In 2008, Chinese economy was inherently hurt due to the Global Financial Crisis (GFC) with huge impact on its markets, financial institutions, real estate and spillover impact over other sectors as well. The foreign direct investment (FDI) decreased nearly 50 billion USD with a decrease of 42 per cent in 2009 (Li, Willett \& Zhang 2012).

\subsubsection{Post-Global Financial Crisis: Phase Three}

In the post- 2008 crisis, Chinese society has seen more development activities than any other major economies. In the aftermath of the crisis, the Chinese economy rejuvenated to still stay ahead of major economies of its time in terms of growth rate. Interestingly, estimates by International Monetary Fund (IMF) have also indicated that the Chinese economy will leap over the US economy within the next few decades to become the largest economy in the world. Besides the country is home to the largest investment of foreign capital for sometime averaging nearly 100 billion USD on an annual basis. China became known as the "world's workshop" within a small time-frame and has eclipsed all countries in terms of quantity of goods produced and exported on an annual basis. A major indicator of its economic might is its exports to the rest of the globe. In last decade, the Chinese exports amounted to 24.39 per cent of its total GDP (but less than the previous decadal average of 26.57 per cent) thereby enabling it to create the largest forex reserves in the world (Kohlmann 2018; The World Bank Group 2018a).

From the year 2008 until 2017, the GDP of the country increased threefold from 4.6 trillion USD to 12.24 trillion USD, accounting for 14.9 per cent of the global GDP (Country Economy 2018; Knoema 2018). In 2014, the 
economy leapt ahead of the US, to become the largest economy in terms of GDP in PPP (purchasing power parity) terms. In 2017, the total GDP of the country reached 12.24 trillion USD and accounted for 19.74 per cent of the global growth as well (Trading Economics 2018). In terms of economic wherewithal of companies-based in China, in the post-Crisis period huge strides have been made by Chinese companies within the last decade. Zucchi (2018) has estimated that of the largest global initial public offerings (IPOs) so far, the top three companies are based in China and accounts for 36 per cent of the IPOs of total top ten multinational companies. The three companies Alibaba Group Holding Ltd., Agricultural Bank of China Ltd. and Industrial and Commercial Bank of China with 25 billion USD, 22.1 billion USD and 21.9 billion USD respectively. Alibaba reportedly broke into the top ten global companies in terms of share value, immediately after it broke the record (at 25 billion USD) for the largest Initial Public Offering (IPO) by a company in the history of share market. Thus, a major contributor towards this bewildering rise of China's economic wherewithal can be attributed to the digitalisation initiatives by the State in the lines of (state) neoliberalistic policies (Zucchi 2018). Besides, with the largest number of internet users in the world (731 million netizens) and one of the highest increases in online transaction value (e-commerce) among large economies (19.6 per cent per annum) China controls nearly 39 per cent of global online retail market (Nian 2017). But later, China initiated a huge nationalistic drive that focuses on a 'Technological Revolution' to help it become a 'tech superpower'. Currently, it is even standing toe to toe with Silicon Valley in terms of research, innovation and creativity, mainly because of the institutionalisation of strategies, initiatives and policies for integration of digitalisation within the country

\subsection{Digitalisation in China}

At the beginning of the 21st century, the integration of digital technologies in industries enabled greater growth in China, which often made the economy to be compared to that of growth of major economic superpowers of each era, the 19 th century Germany and the $20^{\text {th }}$ century Japan. Fareed Zakaria in his article in Foreign Affairs titled The Future of American Power (2008) was quoted saying that "manufacturing has... been... shifting to the developing world and turning the United States into a service economy" (Zakaria 2008). The void left by the US in relation to manufacturing was filled by China in the 21st century. This led to the rise of China as an 'Entrepreneurial Empire' capable of leaping over the US in the future. China overturned century-old predictions of unilateral domination by the US and forced all the powers to consider China as a major part of the system (James 2005). 
Since the middle of the 1990s, the Chinese government started promoting internet for providing with an integrated approach to economic growth as well as e-governance (Qiang 2003). Besides providing more control over the population, the internet revolution provided more economic wherewithal to the administration as well as the population. Those later years saw the emergence and development of four major internet-cum-tech companies Tencent (1998), JD.com (1998), Alibaba (1999) and Baidu (2000); all of whom as of May 2018 account for a combined 19.49 per cent of the total global market value (Tencent 2018; JD.COM 2018; Alibaba Group 2018; Baidu 2018; Molla 2018). This foundation later on enabled in supplementing the economic revolution in the country and the emergence of the middle class in urban China. Interestingly, what was laid by the government for internet revolution in the country, also helped accelerate the Internet of Things and digitalisation of the industry as China turned into a hub of innovation. In 2004, the National People's Congress (NPC) in China decided to pursue modernisation of the country but with emphasis on "balanced, humancentred, and environmentally friendly" approach. An increased emphasis on internet and e-governance were given by the government (Jiang 2004).

\subsubsection{The Emergence of the Internet of Things (IoT)}

According to Marr (2017), the manner in which IoT has emerged in the industrial sector and among businesses will transform the economy, especially by the integration and institutionalisation of the Internet of Things (IoT). This is because transactions, production and commodification of objects take place at a faster and more efficient manner, and will be the features of a modern-day industries. Most importantly, entrepreneurs, manufacturers and industrialists will be able to gather more, precise information about demands on a real-time basis directly from the consumers (Marr 2017; Schumpeter 1947). Yarmoluk and Truempi (2018) have explained that the digitalisation of the industrial sector, also called the Industrial Internet of Things (IIoT) is a segment of IoT. To them being "the Fourth Industrial Revolution or Industry 4.0 or IIoT is the digitalisation of industrial assets and processes." It connects the owner/ chief executive officer/ manager with the machines, workers, products, services, locations/sites vendors as well as partners/ stakeholders.

In 1999, Kevin Ashton, a technology pioneer, innovator and consumer expert coined the phrase "the Internet of Things" during his presentation to his company Procter and Gamble (P\&G) (Gabbai 2015; Lueth 2014). Ashton who was working in the supply chain optimization section was keen on commercialising the RFID (Radio-frequency identification) technology and 
titled his presentation "The Internet of Things." A decade later Ashton wrote an article titled "That 'Internet of Things' Thing" in the RFID Journal, where he stated that:

If we had computers that knew everything... [they could] track and count everything... [these] computers with their own means of gathering information... can see, hear and smell the world for themselves, in all its random glory (Ashton 2009).

Later a number of definitions and conceptualizations on what Internet of Things (abbreviated as IoT) came through various literature. Chui, Löffler and Roberts (2010) defined IoT as "the physical world itself [in itself] becoming a type of information system." Here the objects and the environment are connected to the Internet and provide large volumes of data (Big Data!) and can communicate back and forth and act as a tool with the user. According to Narang Kishor of Narnix Technolabs, "The IoT... is... about connecting everything that exists with everything else... [It] is a neural network of globally aware, intelligent and heterogeneous devices connected with each other in multiple ways" (TeamEfy 2017).

Naseer (2017) explains that by 2020 the industries that will have IoT integrated into them are manufacturing, energy \& utilities, agriculture, healthcare, automobiles and many more. Anil (2017) stated that India along with China will be leading in the coming future of the Fourth Industrial Revolution. Recently, Buia (2018) have ascertained that data and digitalisation have provided "value-creation choices" in diverse industries like mining, pharmaceuticals and energy, while Mori, Saleh, Sellschop \& Hoey (2018) argues that the new digital technologies have already being used to increase control and optimization in the metals industry. This will influence the future setting up of production units, further investment and designing of products and increase revenue as well. This will also transform the manner in which manufacturing is done and probably reduce wastage of resources, goods and costs of production in the economy, in addition to providing with increased innovation, competitiveness and profitability in exports.

Custeau (2018a) underlines that this digital transformation in the industries will increase production efficiency by 25 per cent, reduce the cost of construction and expansion by 30 per cent, increasing processing efficiency by 15 per cent and halt the decline in production by seven per cent. The IoT will transform the industries themselves, especially for manufacturing based on the demand cycle of the economy that which provides information on a real-time basis. A transformation of the economy into a digital economy that integrates manufacturing could tap and exploit the domestic demand at the 
fullest length. While Jankowski (2016) stated the emerging revolution that $5 \mathrm{G}$ technology could have on digitalisation, Custeau (2018b) emphasizes that the emergence and use of "sensing technology, machine learning, big data and predictive analytics... are allowing companies to shift to a new, IoT-enabled proactive maintenance solution." Currently, with the emergence of 'Industrial Revolution 4.0' manufacturing is undergoing a digital revolution, particularly dependent and invariably driven by internet, artificial intelligence (AI), (big) data, computing capabilities and more importantly automation (ENISA 2017).

\subsubsection{Policy Landscape}

The Ministry of Industry and Information Technology (MIIT), the ministry in charge of "administration of China's industrial branches and information industry." The integration of digitisation and industries was primarily the responsibility given to this ministry (The State Council People's Republic of China 2018; The State Council People's Republic of China 2014). Currently, the prominent economic and industrial policies with particular focus to digitalisation are the 'Made in China 2025', National Medium- and Long-Term Science and Technology Development Plan Outline (2006-2020) (MLP), the State Council Decision on Accelerating and Cultivating the Development of Strategic Emerging Industries (SEI Decision), Notice on Issuing 13th Fiveyear Strategic Emerging Industries Development Plan, 12th Five-year National Strategic Emerging Industries Development Plan (12th Five-year SEI Plan), Innovation-Driven Development Strategy (IDDS) 2016, Chinese Communist Party's (CCP's) 2013 Third Plenum Decision, IDAR Strategy i.e.,'Introducing' (引进: yinjin), 'Digesting' (消化: xiaohua), 'Absorbing' (吸收: xishou), and 'Reinnovating' (在创新: zai chuangxin), the National Informatization Development Strategy (2006-2020) that comprises of National Integrated Circuit Industry Development Outline, the Internet Plus Plan and the "Broadband China" strategy (USTR 2017; MIIT 2015; Permanent Mission of the People's Republic of China to the UN 2018). The rejuvenation of China was primarily dependent on its industrial policies and related legislation and strategies. Though there are many industrial policies that have contributed towards China emergence and rejuvenation at the global level, the Chinese State has projected the 'Made in China 2025' as the frontline policy for entailing China a 'world power status' in the 'Age of Digitalistion'. 


\section{3. 'Made in China 2025': A Case Study}

The Made in China 2025 is one of the landmark strategic plans in the history of modern Chinese State since that of Deng Xiaoping's "reform and openingup" in the "70s. It was brought with the intention of enabling China's rise into a world power and to elevate it to the superpower status, and to transform the domestic and global industrial sector. Though first official discussion on 'Made in China 2025' (中国制造2025: zhongguo zhizao 2025) took place at the national level in 2011, it was only adopted two years later in 2013. It was drafted by the MIIT with inputs from experts, policymakers and other stakeholders from the China Academy of Engineering as well as various parts of the country and abroad (Kennedy 2015). On May 8, 2015, the State Council of People's Republic of China issued a Notice of the State Council on Printing and Distributing "Made in China 2025" directing all governmental institutions, organisations and agencies to implement the Made in China 2025. On May 19, the State Council issued the Made in China 2025 national plan that emphasised on "building Chinese manufacturing sector to become a leader in world's manufacturing industry” (把我国建设成为引领世界制造业 发展的制造强国: ba woguo jianshe chengwei yinling shijie zhìzao ye fazhan de zhizao qiangguo). It stated the need for China to focus on economic restructuring, upgrading overall national strength, safeguarding national security, and the goal of becoming a world power in the coming three decades i.e., 2025, 2035 and 2049 respectively. A major area of focus of this "reindustrialisation strategy" would be "intelligent manufacturing." It specifically entails on intelligent equipment and smart factories that are particularly dependent on information systems, exchange and coordination. China intends to transform the existing methods of manufacturing and is looking at integrating innovative technological aspects. These include network crowdsourcing, collaborative design, large-scale personalized customization, precise supply-chain management, full lifecycle management, transformative e-commerce and the like. This could reshape the existing domestic, regional and Global Industrial Value Chains (GIVC) (MIIT 2015).

According to the policy-makers in China, the emergence of technological and scientific transformations around the globe have a huge impact on every country. Thus for China for elevating its status as a world power through 'Technological Revolution', conventional policies and strategies wouldn't suffice. The emergence of 3-D printing, mobile internet, cloud computing, big data, intelligent manufacturing is but leading the transformation of manufacturing methods. Besides, network crowdsourcing, collaborative design, large-scale personalized customization, precise supply chain 
management, full lifecycle management, e-commerce and the like are reshaping the industrial value-chain systems. There are also new areas of manufacturing like smart terminal products such as wearable smart products, smart home appliances and smart cars (Ibid.). Figure 1 shows the estimated 'innovative disruptability' of China's 'Made in China 2025' in major industrial countries.

Figure 1: Estimated 'Innovative Disruptability' of China's 'Made in China 2025' in major industrial countries

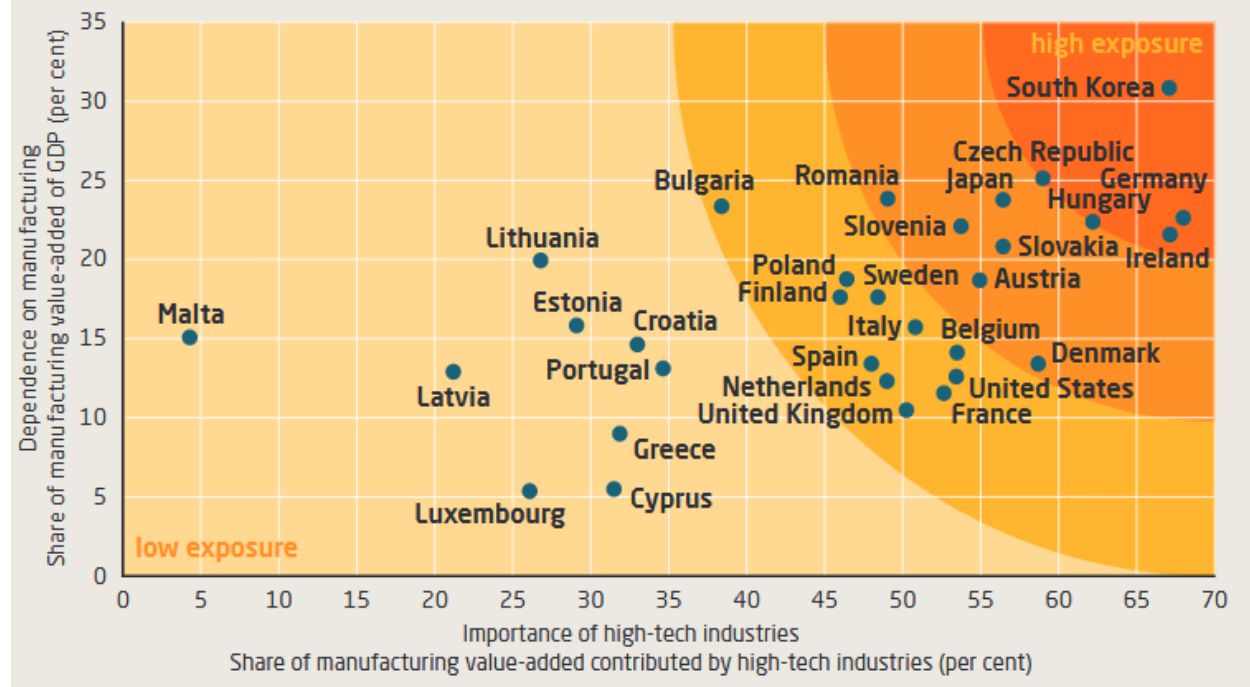

Source: Wübbeke et al. 2016.

Wübbeke et al. (2016) in the report titled MADE IN CHINA 2025: The making of a high-tech superpower and consequences for industrial countries argues that this strategy was borrowed from the German concept of 'Industry 4.0' as well as the 'Industrial Internet' of USA. This focuses on re-industrialisation, re-modernisation and the upgrading Chinese industries in lines with the emerging Fourth Industrial Revolution and IoT. It inherently requires technology transfer from foreign investors, especially through joint ventures, transfer of the patent, skill training and indigenous technology development as well. This initiative by the Chinese State "targets" all high-tech industries and strategic technologies from companies of all major economies. China has also institutionalised funds at the national level, namely the Advanced Manufacturing Fund (3.13 billion USD) and the National Integrated Circuit Fund (22 billion USD) (Wübbeke et al. 2016, 6-7). 


\subsection{Challenges}

A major challenge for China has been the emergence of economic nationalist policies by its major trading partners like the US. The increasingly protectionist policies will hinder the chances of China to elevate its status to a world superpower in manufacturing. This coupled with competitiveness of companies and labourers based in India and South Asian nations will provide huge competition and drastically affect the surplus, in terms of the balance of trade as well as economic wherewithal. Secondly, the emergence of industrial robots and other related technologies is eventually expected to displace the existing working-cum-industrial population. With the comparative advantage of (current) Chinese labour wages (to those in developed countries), the riskaverse nature of the Chinese companies (on upgrading existing infrastructure) and the huge gap in capital requirement for further investment there won't be much "hyped" job loss in the private sector companies based in China. The labour-intensive industries in the private sector are not expected to transform themselves in a few years unless there is a huge flow of capital investment and in companies with joint ventures. But interestingly, the prominent companies in China with international clientele like Tencent, Alibaba, Baidu, Huawei as well as foreign companies with a manufacturing base in China are expected to pour in huge investments on automation and digitalisation. This coupled with the changing production patterns in Chinese State-Owned Enterprises (SOEs) will expectedly displace industrial workers in China. This is expected to have a huge impact on the economy, since data and reports show China having very low labour productivity in comparison to USA, Germany, Japan and Malaysia in the last decade (Schuman 2017; McKinsey Global Institute 2016; Wübbeke, Meissner, Zenglein, Ives \& Conrad 2016, 15). Based on the reports of last three years, the labour force participation rate in China has averaged around 69.34 per cent, while other countries like Malaysia (64.38 per cent), USA (62.02 per cent), Germany (60.42 per cent) and Japan (60.22 per cent) are relatively lower than China. Though it can be argued that these countries have very less population with respect to China, the huge difference with India (53.89 per cent) reveals the huge implications of large-scale displacement of industrial workers due to nation-wide automation and digitalisation; as well as the further issues that could cause on would cause have on the socio-economic and political stability of China (The World Bank Group 2018c).

\subsection{Initiatives and (counter) measures}

China has already begun taking (counter) measures and initiatives for dealing or circumventing the hindrances to its elevation to a world power. This 
relates to initiatives to employability of Chinese workers in the future, and to prevent and/ reduce competition from other State actors. One, through the Belt and Road Initiative (BRI) as well as increased land acquisitions and constructions in foreign nations, it have so far given priority to the Chinese labour force. This can reduce issues and discontent of unemployability in China while providing greater control over the foreign projects in which China has largely invested or has loans for. Besides, this will increase regional integration and connectivity (reminiscent of the 'Marshall Plan' of the US), thus entailing an increased economic prosperity, inter-cum-intra connectivity for China. This could also help reduce the impact of economic nationalist policies that are increasingly adopted by countries like USA. China have provided for transfer of core technologies, increased preferences for joint ventures (JVs) and increased State funding for research and development (R\&D) as well as innovation. Secondly, China has increased the inclusion of surveillance technologies in its workers. These can provide an increased awareness and control over the mind of the worker, helping companies to determine the best action and remedy for any kind of potential discontent or emotional turmoil. It have also increased the investment in the education, industry and high-tech skill development to help skill-up or provide new technical and non-technical skills to the workers and citizens. This will help increase employability and diversify options for Chinese workers in the domestic as well as foreign markets, reduce the instant job loss for conventional workers being able to transfer to new jobs as well as reduce future unemployment rates for the younger generation as well. This will also help the country increase foreign remittances as well. But still, there are emerging complexities and challenges in the international stage that are linked with the political economy of power and politics (MIIT 2015; China Daily 2016; Wübbeke, Meissner, Zenglein, Ives and Conrad 2016).

\section{Methodology}

This study relies on content analysis, historiographic and qualitative approaches of various sources. The sources content analyses and historiographic approach include documents, reports and other related literature from international and national organisations, agencies and groups. For the latter (qualitative) approach is based on the case study of 'Made in China 2025', and on narratives of various stakeholders as well. 


\section{Conclusion}

Nearly two hundred years after Napolean's remark on the power and capability of China, every nation perceives China as a (giant) power capable of displacing any (poles of) 'power' and even determining the balance of power of the world. For China this has been possible due to the pursuance of (state) neoliberalistic initiatives by the Chinese state. The activities it undertook to strengthen the socio-economic and political structures (climate) transformed the nation to lay the foundations of the country. The policies and strategies that was developed in the late 70 brought in a new drive for rejuvenating market and wealth generation within the country. The largely dedicated economic reconstruction and manoeuvring based on '(In)visible Hand', especially (re)industrialisation by increasing foreign technology transfer, joint ventures and the increased foreign direct investment (FDI) turned the strides in the history of modern China.

Interestingly, development have been (and still sometimes have been) associated with neoliberalistic policies undertaken by States. This narrative has been one that is considered a mainstream political and economic path to elevate development and wealth generation in a country. The 'China model' has and still is re-writing the mainstream narrative of neoliberalist economics, one which could be compared to the origins of post-behavioural revolution at the beginning of the 20th century. It is different from the conventional understanding of neoliberalism and the concepts that emphasised and adhered to Smithian and Ricardian arguments on complete exclusion of State from controlling and manipulating market. The narrative emphasises on free market, innovation devoid of State intervention and the 'Invisible Hand' that leads to prosperity, increased wealth generation and standard of living. But as scholars like Ong had argued about China, the State controls the market agents, though providing leeway to some extent and for some parameters. This led to the rise of the new form(s) of neoliberalism in Asia, that started emerging and became perceived to be far better in terms of economic development, inequality, income distribution and standard of living of the Global North.

Interestingly, in the $21^{\text {st }}$ century especially after the post-2008 period, China redesigned its industrialisation process(es) and activities. This was particularly because of the emergence of the Fourth Industrial Revolution (4IR) or Industry 4.0 globally. The cyber-physical systems and Internet of Things (IoT) have but transformed the industrialisation process(es) across the major economies in the world, with China being in its forefront. Currently, China has emerged as the leader in innovation with regard to IoT and is in a transitionary period of integrating it into its manufacturing sector. It has 
emerged as a world leader in innovation in IoT surpassing global leaders like Germany, USA and other European nations.

China has come up with the 'Made in China 2025' strategy that intends to incorporate the digitalisation process, and help rejuvenate as well as upgrade the industrial sector in China, help reverse the current decline of its exports. The Chinese State leaders have openly proclaimed the goal of becoming a superpower in manufacturing, with major emphasis on 'Made in China 2025'. Various reports, international organisations as well as scholars have concurred on this argument becoming a reality in the next few decades. Even the trade war between China and US is a 'technology war' rather than just a 'trade war', one which will change the future hegemonic polarity of international politics. A major bottleneck will be the increase in wages and unrest among the working population. Though labour costs as a whole are expected to be mostly stable over the next few years, the expected wage rise will have huge implications for the export-oriented economy. The increasing nature of economic nationalist tendencies of various countries like the US and competencies of India and South Asian nations will be all challenges to China. Besides, the increasing trend of Chinese companies to displace or replace the human workers with robots and digital technologies even though could provide a comparative advantage in terms of cost of production and man hours will probably increase worker unrest and protests in a much larger scale.

\section{References}

Alibaba Group. 2018. "Company Overview." https://www.alibabagroup.com/en/about/overview. Accessed on September 23, 2018.

Anil, Alok Medikepura. 2017. "India and China together can lead the Fourth Industrial Revolution. Here's how." World Economic Forum (WEF). https://www.weforum.org/agenda/2017/11/india-and-china-togethercan-lead-the-fourth-industrial-revolution-here-s-how $/$. Accessed on September 4, 2018.

Ashton, Kevin. 2009. "That 'Internet of Things' Thing." RFID Journal. https://www.rfidjournal.com/articles/view?4986.

Baidu. 2018. "Company Overview." http://ir.baidu.com/phoenix.zhtml?c=188488\&p=irol-homeprofile. 
Accessed on September 23, 2018.

Bertram, Christopher. 1996. “Twilight of Japan?.” Project Syndicate. https://www.project-syndicate.org/commentary/twilight-ofjapan?a_la =english\&a_d=536608be1a91c10c78c04658\&a_m=\&a_a=click\&a_ $\mathrm{s}=\& \mathrm{a}_{-} \mathrm{p}=\% 2$ Farchive\&a_li=twilight-of-

japan\&a_pa=\&a_ps=\&barrier=accesspaylog. Accessed on September 1, 2018.

Bughin, Jacques and van Zeebroeck, Nicolas. 2018. "Artificial intelligence: Why a digital base is critical." McKinsey Quarterly. https://www.mckinsey.com/business-functions/mckinsey-analytics/ourinsights/artificial-intelligence-why-a-digital-base-is-critical. Accessed on September 21, 2018.

Buia, Calin. 2018. "Shaking up the value chain." McKinsey Quarterly. https://www.mckinsey.com/business-functions/digital-mckinsey/ourinsights/shaking-up-the-value-chain. Accessed on August 31, 2018.

Chang, Sue. 2017. "Here's a chart of the most valuable brands in the world... notice anything?" Market Watch.

https://www.marketwatch.com/story/the-most-valuable-brands-in-theworld-are-overwhelmingly-tech-namesand-american-2017-07-03.

China Daily. 2016. "China to allocate 100 billion yuan for job losses from capacity cuts." China Daily.

http://www.chinadaily.com.cn/business/2016-

02/25/content_23644309.htm. Accessed on August 31, 2018.

China Internet Information Center. 1984. "Building a Socialism with a Specifically Chinese Character."

http://www.china.org.cn/english/features/dengxiaoping/103371.htm. Accessed on August 2, 2018.

Chui, Michael, Löffler, Markus and Roberts, Roger. 2010. "The Internet of Things." McKinsey \& Company. https://www.mckinsey.com/industries/high-tech/our-insights/theinternet-of-things. Accessed on September 2, 2018.

Country Economy. 2018. “GDP - Gross Domestic Product.” September 12, 2018. https://countryeconomy.com/gdp?year=1975. 
Custeau, Kim. 2018a. "3 Ways to Improve Workforce Knowledge Retention in Oil \& Gas [Blog]."

https://blog.schneider-electric.com/industrial-software/2018/05/16/3-

ways-to-improve-workforce-knowledge-retention-in-oil-gas/. Accessed on September 20, 2018.

Custeau, Kim. 2018b. "Improve Reliability in Chemical Manufacturing with Predictive Asset Analytics [Blog]."

https://blog.schneider-electric.com/industrial-

software/2018/02/06/improve-reliability-chemical-manufacturing-

predictive-asset-analytics/. Accessed on September 20, 2018.

European Union Agency for Network and Information Security (ENISA) (2017). "Baseline Security Recommendations for IoT in the context of Critical Information Infrastructures."

https://www.enisa.europa.eu/publications/baseline-securityrecommendations-for-iot.

Fish, Isaac Stone. 2016. “Crouching Tiger, Sleeping Giant.” Foreign Policy. https://foreignpolicy.com/2016/01/19/china_shakes_the_world_cliche/. Accessed on August 31, 2018.

Gabbai, Arik. 2015. "Kevin Ashton Describes "the Internet of Things"." Smithsonian Magazine.

https://www.smithsonianmag.com/innovation/kevin-ashton-describes-theinternet-of-things-180953749/. Accessed: September 2, 2018.

Gang, Fan. 1996. "The Clash Of China's Two Economies.” Project Syndicate. https://www.project-syndicate.org/commentary/the-clash-of-china-s-twoeconomies?a_la=english\&a_d=536608a61a91c10c78c008e2\&a_m=\&a_a=clic $\mathrm{k} \& \mathrm{a} \_\mathrm{s}=\& \mathrm{a}$ _p$=\% 2 \mathrm{Farchive} \& \mathrm{a}$ _li $=$ the-clash-of-china-s-twoeconomies\&a_pa=\&a_ps=\&barrier=accesspaylog. Accessed on September 2, 2018.

James, Harold. 2005. "How Economic Superpowers Rise." Project Syndicate. https://www.project-syndicate.org/commentary/how-economicsuperpowersrise?a_la=english\&a_d=536608c11a91c10c78c04f92\&a_m=\&a_a=click\&a_s= \&a_p=\%2Farchive\&a_li=how-economic-superpowersrise\&a_pa=\&a_ps=\&barrier=accesspaylog. 
Jankowski, Simona. 2016. "The 5G Revolution: The Internet of Things Meets Everything." Goldman Sachs. https://www.goldmansachs.com/insights/pages/iot-meetseverything.html?cid=PS_01_35_07_00_01_16_01\&mkwid=8luESsWm?cid=PS _01_35_07_00_01_16_01\&mkwid=8luESsWm. Accessed on September 2, 2018.

JD.COM 2018. “OUR HISTORY.” http://corporate.jd.com/ourHistory. Accessed on September 23, 2018.

Jiang, Wenran. 2004. “China's Silent Rural Revolution.” Project Syndicate, https://www.project-syndicate.org/commentary/china-s-silent-ruralrevolution?a_la $=$ english\&a_d=536608b31a91c10c78c02981\&a_m=\&a_a=clic $\mathrm{k} \& \mathrm{a}_{-} \mathrm{s}=\& \mathrm{a}_{-} \mathrm{p}=\% 2 \mathrm{Farchive \& a} \mathrm{i}=$ china-s-silent-ruralrevolution\&a_pa=\&a_ps=\&barrier=accesspaylog. Accessed on September 23, 2018.

Kennedy, Scott. 2015. "Made in China 2025." Centre for Strategic and International Studies.

https://www.csis.org/analysis/made-china-2025. Accessed on September 5, 2018.

Knoema. 2018. "World GDP Ranking 2017| GDP by country | Data and Charts." https://knoema.com/nwnfkne/world-gdp-ranking-2017-gdp-by-countrydata-and-charts. Accessed on August 19, 2018.

Kohlmann, Thomas. 2018. "From the world's workshop to the world's tech hub: China's economic leap forward." Deutsche Welle. https://www.dw.com/en/from-the-worlds-workshop-to-the-worlds-techhub-chinas-economic-leap-forward/a-43688091. Accessed on September 1, 2018.

Li, L., Willett, T. D., \& Zhang, N. 2012. The Effects of the Global Financial Crisis on China's Financial Market and Macroeconomy. Economics Research International, 1-6. DOI: 10.1155/2012/961694. Accessed on September 1, 2018.

Lopes, Dawisson Belém. 2017. “Asia's Exceptional Neoliberalism." The Diplomat. 
https://thediplomat.com/2017/08/asias-exceptional-neoliberalism/. Accessed on September 4, 2018.

Lueth, Knud Lasse. 2014. "Why the Internet of Things is called Internet of Things: Definition, history, disambiguation." IoT Analytics. https://iot-analytics.com/internet-of-things-definition/. Accessed on September 2, 2018.

Marr, Bernard. 2017. "What Is The Internet Of Things -- A Complete Beginner's Guide For Anyone." Forbes.

https://www.forbes.com/sites/bernardmarr/2017/04/10/what-is-theinternet-of-things-a-complete-beginners-guide-in-2017/\#af903045982d. Accessed on September 2, 2018.

McKinsey Global Institute. 2016. "Meeting China's productivity challenge." McKinsey \& Company.

https://www.mckinsey.com/featured-insights/china/meeting-chinasproductivity-challenge. Accessed on September 5, 2018.

Ministry of Industry and Information Technology (MIIT). 2015. 'Guowuyuan guanyu yinfa “zhongguo zhìzao 2025” de tongzhi' (国务院关于印发《中国制 造2025》的通知) [Notice of the State Council on Printing and Distributing "Made in China 2025"]."

http://www.miit.gov.cn/n973401/n1234620/n1234622/c4409653/conten t.html. Accessed on September 5, 2018.

Molla, Rani. 2018. "Mary Meeker: China now has nine of the world's biggest internet companies - almost as many as the U.S." Recode. https://www.recode.net/2018/5/30/17385376/mary-meeker-kleinerslides-code-conference-chinese-tech. Accessed on September 2, 2018.

Mori, Lapo, Saleh, Tamim, Sellschop, Richard and Hoey, Michel Van. 2018. "Unlocking the digital opportunity in metals." McKinsey \& Company. https://www.mckinsey.com/industries/metals-and-mining/ourinsights/unlocking-the-digital-opportunity-in-metals. Accessed on September 12, 2018.

Naseer, Nayab. 2017. "5 key industries where IoT will cause major disruptions in 2020. [Blog post]." 
https://suyati.com/blog/5-key-industries-iot-will-cause-major-disruptions2020/. Accessed on September 2, 2018.

Nian, Yao. 2017. “China's online retail sales account for 40 percent of global market." China Global Television Network group (CGTN).

https://news.cgtn.com/news/3d497a4e3341444e/share_p.html.

Office of the united states trade representative (ustr). 2017. "Findings of the investigation into China's acts, policies, and practices related to technology transfer, intellectual property, and innovation under section 301 of the trade act of 1974."

https://ustr.gov/sites/default/files/Section\%20301\%20FINAL.PDF, 3-18. Accessed on September 1, 2018.

Ong, A. 2006. Neoliberalism as exception: Mutations in citizenship and sovereignty. Durham: Duke University Press, 98.

Permanent Mission of the People's Republic of China to the UN. 2018. "China's 13th Five-Year Plan."

http://www.china-un.org/eng/zt/China123456/. Accessed on August 31, 2018.

Qiang, Xiao. 2003. “China's Virtual Revolution.” Project Syndicate. https://www.project-syndicate.org/commentary/china-s-virtualrevolution?a_la=english\&a_d=536608571a91c10c78bf4b47\&a_m=\&a_a=clic $\mathrm{k} \& \mathrm{a}_{-} \mathrm{s}=\& \mathrm{a}_{-} \mathrm{p}=\% 2 \mathrm{Farchive} \& \mathrm{a} \_\mathrm{li}=$ china-s-virtualrevolution\&a_pa=\&a_ps=\&barrier=accesspaylog. Accessed on September 2, 2018.

Rodrik, Dani. 2003. "Reforming Economic Reform.” Project Syndicate. https://www.project-syndicate.org/commentary/reforming-economicreform?a_la=english\&a_d=5366085b1a91c10c78bf565b\&a_m=\&a_a=click\&a _s=\&a_p=\%2Farchive\&a_li=reforming-economicreform\&a_pa=\&a_ps=\&barrier=accesspaylog. Accessed on August 22, 2018.

Rommann, Ryan. 2013. "Beijing Takes Cues from the Washington Consensus.” The Diplomat. https://thediplomat.com/2013/12/beijing-takes-cues-from-thewashington-consensus/. Accessed on September 11, 2018. 
Schuman, Michael. 2017. "China Has World's Biggest Productivity Problem.” The Diplomat.

https://thediplomat.com/2017/08/asias-exceptional-neoliberalism/. Accessed on September 5, 2018.

Schumpeter, J. A. 1947. Capitalism, Socialism, and Democracy. New York: Harper \& Brothers.

Shambaugh, D. 2016. The China reader. New York, NY: Oxford University Press., 95, 414.

So A.Y. and Chu Y. 2012. "The Transition from Neoliberalism to State Neoliberalism in China at the Turn of the Twenty-First Century." In Developmental Politics in Transition, 166-187. London: Palgrave Macmillan.

Sup C., Fine B., Weiss L. (eds). 2012. Developmental Politics in Transition. International Political Economy Series. Palgrave Macmillan, London.

TeamEfy. 2017. "Security in IoT." Smart World. https://smart.electronicsforu.com/3087/.

Tencent. 2018. "About." https://www.tencent.com/en-us/. Accessed on September 23, 2018.

The State Council People's Republic of China. 2014. "Ministry of Industry and Information Technology."

http://english.gov.cn/state_council/2014/08/23/content_2814749830359 40.htm. Accessed on August 19, 2018.

The State Council People's Republic of China. 2018. "State Council." http://english.gov.cn/statecouncil/. Accessed on August 19, 2018.

The World Bank Group. 2018a. "Exports of goods and services (\% of GDP)." https://data.worldbank.org/indicator/NE.EXP.GNFS.ZS. Accessed on September 5, 2018.

The World Bank Group. 2018b. "GDP (current US\$)." https://data.worldbank.org/indicator/NY.GDP.MKTP.CD?end=2008\&start= 1976. Accessed on August 31, 2018. 
The World Bank Group. 2018c. "Labor force participation rate, total (\% of total population ages $15+$ ) (modelled ILO estimate)."

https://data.worldbank.org/indicator/SL.TLF.CACT.ZS. Accessed on September 5, 2018.

Trading Economics. 2018. "China GDP.”

https://tradingeconomics.com/china/gdp. Accessed on August 31, 2018.

World Trade Organisation (WTO). $2018 . \quad$ "Accessions." https://www.wto.org/english/thewto_e/acc_e/a1_chine_e.htm. Accessed on September 2, 2018.

Wu, Fulong. 2010. How Neoliberal Is China's Reform? The Origins of Change during Transition, Eurasian Geography and Economics 51 (5): 619-631. Doi: 10.2747/1539-7216.51.5.619.

Wübbeke, Jost, Meissner, Mirjam, Zenglein, Max J., Ives, Jaqueline, \& Conrad, Björn. 2016. “MADE IN CHINA 2025.” MERICS. https://www.merics.org/sites/default/files/201807/MPOC_No.2_MadeinChina2025_web.pdf. Accessed on September 5, 2018.

Yarmoluk, Dan and Truempi, Craig. 2018. "Predictive Analytics in Industrial IoT." Datascience.com blog.

https://www.datascience.com/blog/predictive-analytics-in-industrial-iot. Accessed on September 13, 2018.

Zakaria, Fareed. 2008. “The Future of American Power.” Global Policy Forum. https://www.globalpolicy.org/component/content/article/155history/26016.html. Accessed on September 30, 2018.

Zhang, Yongjin. 2013. "The Tribute System." Oxford Bibliographies. http://www.oxfordbibliographies.com/view/document/obo9780199920082/obo-9780199920082-0069.xml. Accessed on November 30, 2018.

Zucchi, Kristina. 2018. “Top 10 Largest Global IPOs Of All Time.” Investopedia, https://www.investopedia.com/articles/investing/011215/top-10-largestglobal-ipos-all-time.asp. 